\title{
Governance and Economic Performance in Developing Countries: an Empirical Study
}

\author{
Ben Ali Tarek and Zidi Ahmed \\ Higher Institute of Business Administration - University of Gafsa - Tunisia \\ Correspondence should be addressed to: Ben Ali Tarek; tarek.benal@yahoo.fr \\ Received date: 28 April 2013; Accepted date: 18 May 2013; Published date: 15 August 2013 \\ Academic Editor: Noorsidi Aizuddin Mat Noor
}

Copyright ( 2013. Ben Ali Tarek and Zidi Ahmed. Distributed under Creative Commons CC-BY 3.0

\begin{abstract}
The purpose of this paper is to investigate the impact of institutional quality on economic growth. Indeed, in recent years economics literature and debates have increasingly referred to the link between governance and economic performances as the appropriate answers to the longstanding questions concerning how economic growth arises. Given this main objective of this study, we first discuss how political institutions contribute to determining economic performance. Then, we present the empirical analysis which identifies the interaction between political institutions and economic growth in developing countries. The main finding of this paper is that improving the quality of political institutions is associated with a decrease in the level of corruption and with a sustainable economic growth in developing countries. Consequently, the institutional failures that characterize developing countries lead inevitably to destabilize their long-term economic growth and a higher degree of democratization would be a better improvement in their economic growth.
\end{abstract}

Keywords: governance, economic growth, developing countries, panel data.

\section{Introduction}

New Institutional Economics (NIE) was presented as a set of currents of thought which involves modernization of the economic analysis of institutions in the nineteen seventies. The objective of the NIE is to determine the role of political institutions in economic coordination. These institutions include laws, property rights traditions, customs, etc. Thus, the NIE has as its main objective to show the importance of political institutions for the development of the economic performance of nations.

In addition, the quality of institutions in a country influences its ability to ensure economic growth and improve the quality of life of its population. As a matter of course, several institutional indicators, such as property rights, governance, political stability, legal systems and the control of corruption in a country were 
used to examine the interaction between institutional quality and economic growth.

Accordingly, several studies have been devoted to the study of the relationship between institutional quality and economic performance. In this context of analysis, several authors, Hall and Jones (1999), Acemoglu, Johnson and Robinson (2002),

Rodrik, Subramanian and Trebbi (2004), Easterly and Levine (2003), and finally Dollar and Kraay (2003) showed that political institutions prompt economic growth.

However, over the years ninety "good governance" is presented as a necessity for the macroeconomic stability of countries. Indeed, "good governance" implies growth and sustained economic development (Frischtack, 1994). Therefore, the target of "good governance" is to improve the economic and social development of this country. It looks like the transparency of public action, control of corruption, free markets, democracy and the rule of law. In this framework, empirical studies showed that governance and the institutional quality are strongly correlated with economic growth. In fact, "good governance" which means, among other things, political rights or the freedom of expression, increases the likelihood that corruption is exposed. In this context, corruption can affect growth through its effect on institutional quality. Increasing the quality of governance necessarily leads to reduced corruption and therefore to an increase in the rate of growth.

The aim of this work is to study the impact of political institutions on economic growth: the case of developing countries.

We intend to divide our study into four sections. In the first section, we will examine the theoretical background of the relationship between political institutions and economic growth. In the second section, we will discuss the link between governance and economic performance in developing countries from a descriptive analysis. The third section presents an econometric analysis of panel data showing the impact of political institutions on economic growth for a sample of thirty developing countries during the period 1998 to 2011. In the final section, we intend to demonstrate some policy implications of our analysis.

\section{Theoretical Background}

Firstly, it gives a great impression of the existence of a negative relationship between economic growth and the level of corruption. Similarly, in a broader context there is a link between governance and economic performance (Kaufman and Kraay, 2002). Indeed, improving the quality of institutions is a necessity. It aimed to achieve a level of sustainable development. Thus, several authors have shown that the difference in the rates of economic growth in different countries can be explained by the difference in the quality of the environment in which agents operate. In fact, this environment includes institutions, rules, laws, policies and government regulations of the country.

Thus, a good institution is characterized by structures and laws that weaken incentives uncertainty and support the efficacy and subsequently increased economic performance.

However, the influence of political institutions on economic growth is well established. In fact, the impact of these institutions, market structures and economic policy are important for economic growth and long-term (Cornelius et al., 2002 to 2003: 2). Indeed, the growth competitiveness index is defined as a group of institutions, structures and policies. In fact, it was designed to define the factors that influence economic growth. To be more precise, it was designed to achieve a growth rate of per capita GDP higher in the medium term (Hu and Sachs, 1997).

In addition, the measurement of the quality of governance is a very difficult work to do. Indeed, in 2003 the World Bank has prepared a set of indicators to assess the quality of governance. In this sense, a distinction is made between governance at the macroeconomic level and governance at the microeconomic level. 
In terms of macroeconomics, governance means "the traditions and institutions through which authority is exercised in a country" (Kaufman, Kraay and ZoidoLobaton, 1999 a and b). For this purpose, resource efficiency and adequacy of policies depend on the ability of leaders. In fact, we can distinguish between "good" or "bad" governance. This differentiation is related to the mechanism of coherence between the government, the market and civil society.

In terms of microeconomics, "corporate governance" refers to "the set of organizational mechanisms that have the effect of delineating the powers and influence management decisions, in other expression, that" govern "their conduct and define their discretionary space "(Charreaux, 1997, p.1). According to this definition, ownership structure and various business partners play a crucial role in determining the organizational framework and rules.

In fact, in the study by Kaufman, Kraay and Mastruzzi (2003), the overall governance is calculated as the average of the following six measures: voice and accountability, political stability, government effectiveness, regulatory quality, rule of law and lack of corruption.

Thus:

The citizen participation and accountability (Voice and Accountability): Measures the ability of a country's citizens to participate and choose the government. It is based on a number of indicators measuring various aspects of the political process, civil liberties and human rights and political.

Political stability and absence of violence (Political Stability): Measures the likelihood that the government in power will be destabilized or overthrown by unconstitutional means and / or violent or threatened by the public such as in the cases of terrorism.

The government effectiveness (Government Effectiveness): Measures aspects of quality and availability of public service, the bureaucracy, the competence of civil servants, the independence of the administration of political pressure and the credibility and transparency of the government's reform commitments and policies.

The burden of regulation (Regulatory Quality): Focuses policies themselves, including measuring the impact of antimarket as price controls or inadequate bank supervision and monitoring as well as the perception of the blockage imposed by excessive regulation in areas such as foreign trade and business climate.

The rule of law (Rule of Law): Includes several indicators that measure the confidence of citizens in accordance with the laws and rules of society. These include perceptions of the incidence of crime, the effectiveness and predictability of the judiciary, and the enforceability of contracts proceedings;

Lack of corruption: Measuring the extent of corruption, defined as the use of public power for personal interests and private profit in terms of wealth and gain corrupted.

Similarly, mention may have the effect of corruption on economic growth in the country. In reality, these effects depend on bureaucratic or institutional characteristics. For this, the level of corruption depends on institutional quality.

In addition, several studies have shown the extent in which the quality of political institutions contributes to determining economic performance. Indeed, Zak (2002) mentioned that the authorities put in place the institutions to protect property rights. In this sense, the author shows that countries with low growth rates are economies that do not adequately defend property rights. In contrast, economies that have property rights effectively carry out economic growth rate higher (Knack, 2002; Schneider, 2005 and Acemoglu et al., 2001). 


\section{Link between Governance and Economic Growth: a Descriptive Analysis}

In this section, we focus on the indirect impact of governance on economic performance. In fact, improving economic growth, governance and the fight against corruption reinforce parallel. Therefore, they are closely related. However, the indirect effects of corruption on governance manifested by limitation of the latter by political competition. Indeed, to be effective as anti-corruption strategy, governance must be associated with a sustainable economic development.
In this sense, several theoretical and empirical studies have demonstrated that governance and corruption are as determinants of the economic performance of countries. Thus, one of the perks of governance on the latter is its ability to limit the negative impact of corruption on economic growth.

At this level, governance increases government accountability to citizens, thereby strengthening their commitments to policies chosen in the fight against corruption.

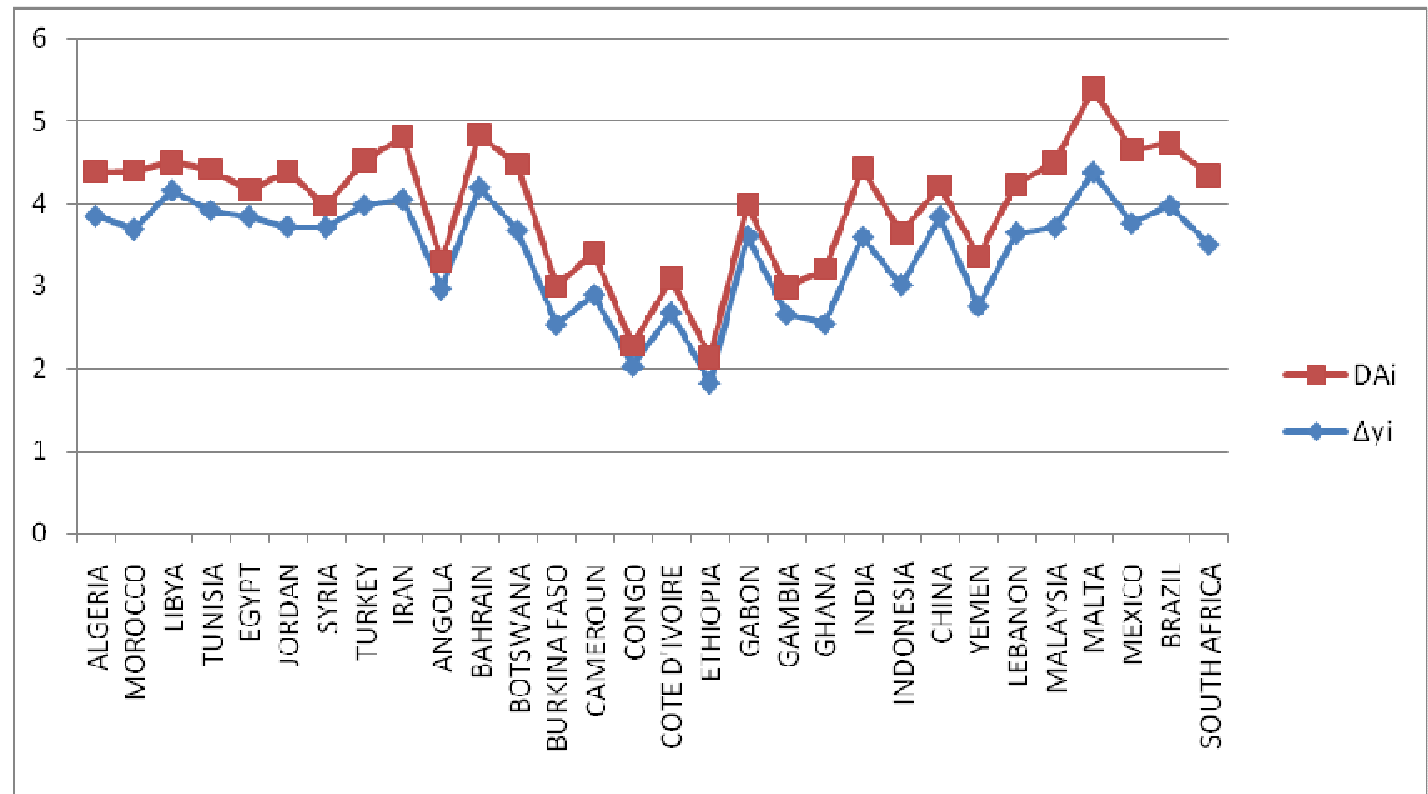

Fig. 1: Evolution of Economic Growth and Democratic Accountability.

Source: Presentation by the author's own outcome data from WDI, 2011 and ICRG 


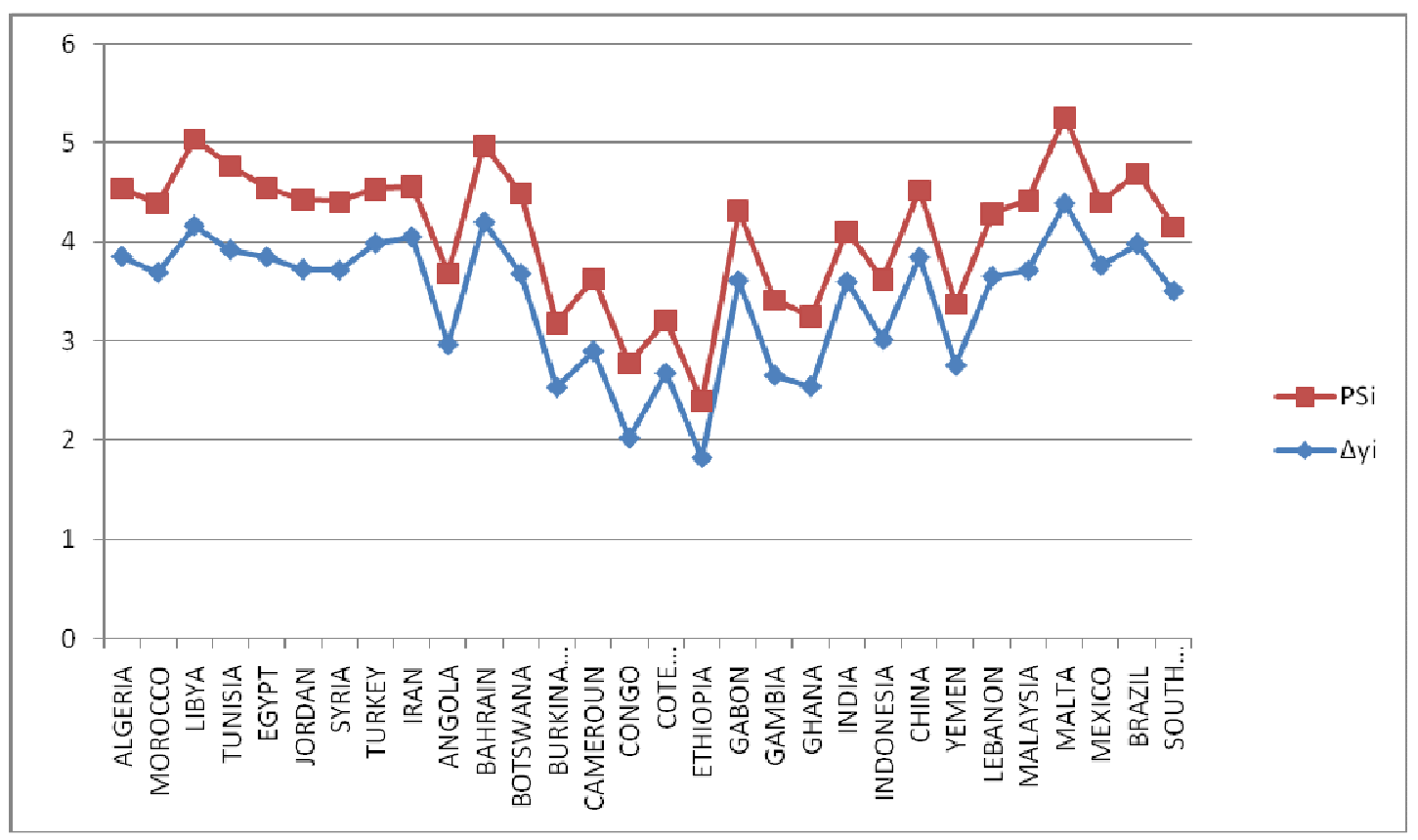

Fig. 2: Evolution of Economic Growth and Political Stability.

Source: Presentation by the author's own outcome data from WDI, 2011 and ICRG

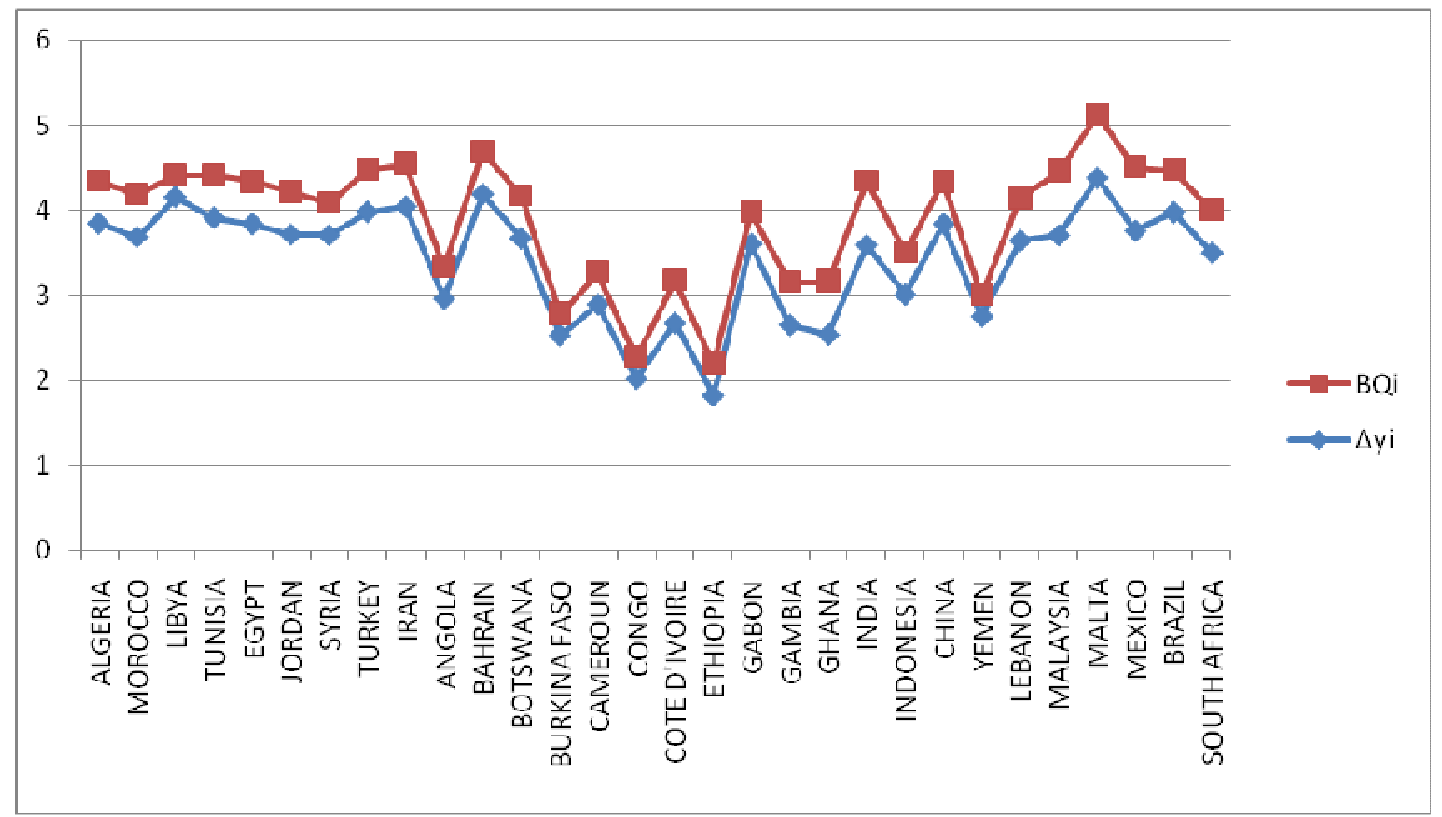

Fig. 3: Evolution of economic growth and Bureaucratic Quality.

Source: Presentation by the author's own outcome data from WDI, 2011 and ICRG 


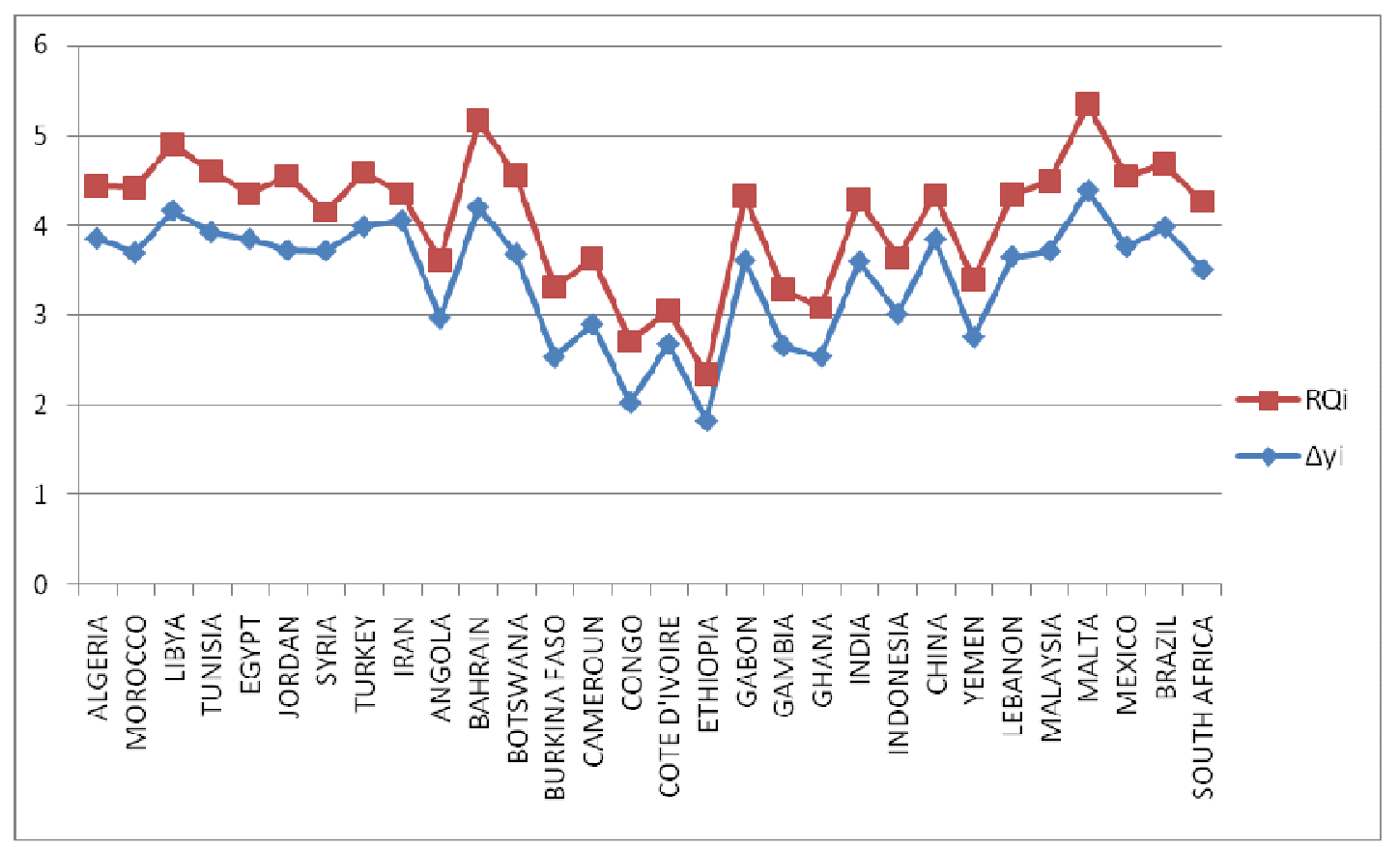

Fig. 4: Evolution of Economic Growth and Regulatory Quality.

Source: Presentation by the author's own outcome data from WDI, 2011 and ICRG

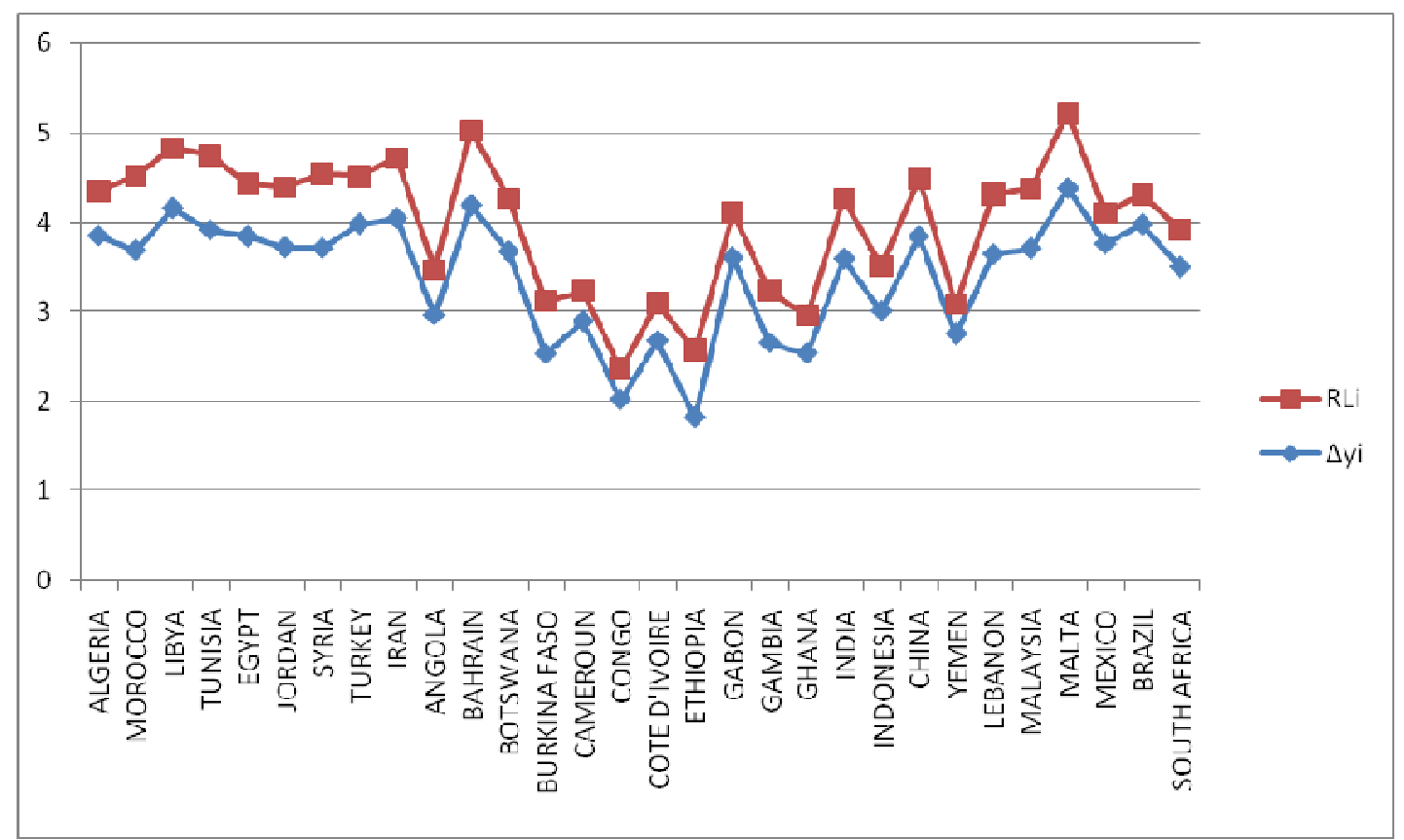

Fig. 5: Evolution of Economic Growth and the Index of the Rule of Law.

Source: Presentation by the author's own outcome data from WDI, 2011 and ICRG 


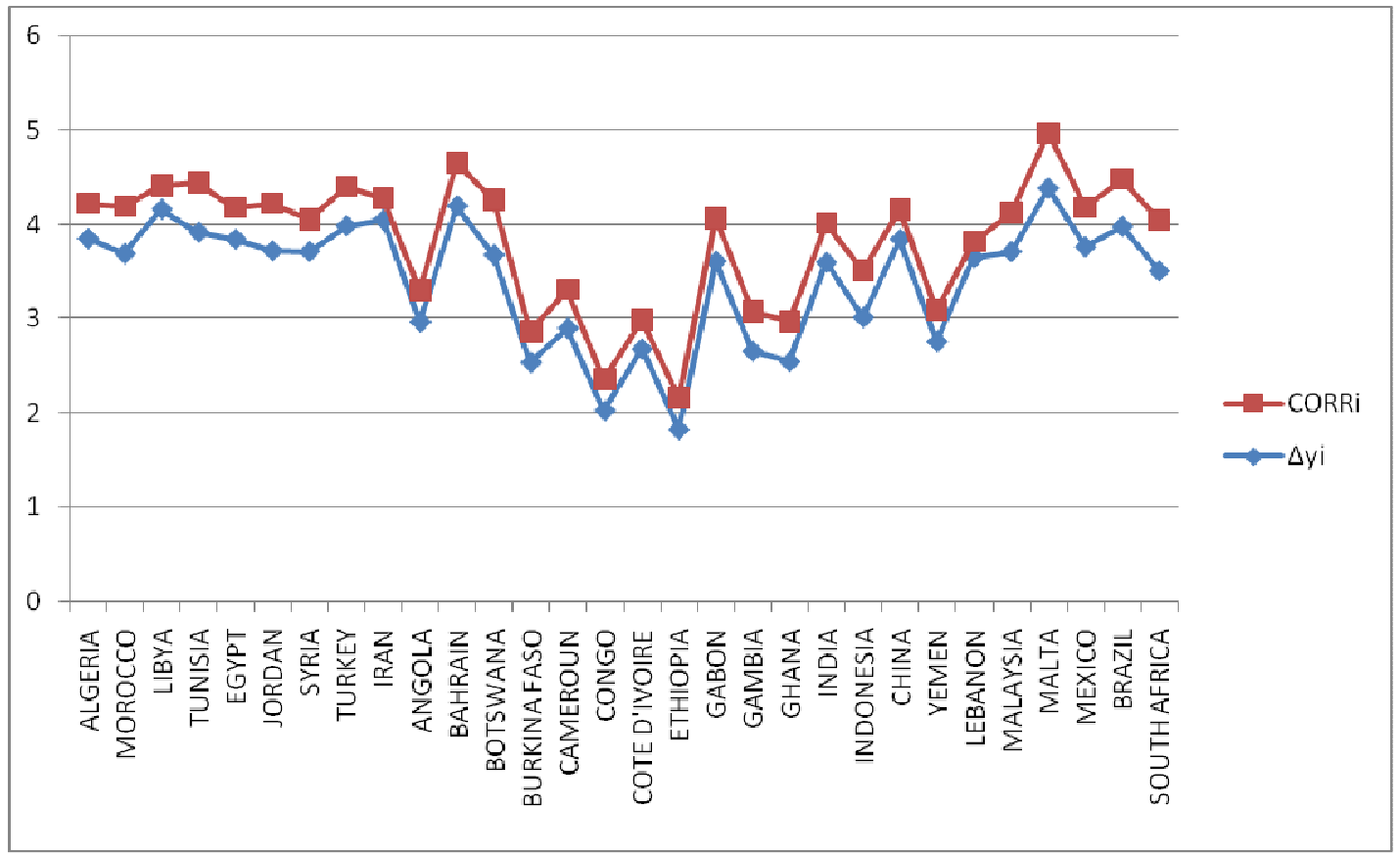

Fig. 6: Evolution of the Economic Growth and Control of Corruption. Source: Presentation by the author's own outcome data from WDI, 2011 and ICRG

Based on this figure (1), we note that there is a good positive correlation between democratic accountability and economic growth: the case of developing countries. Thus, we can report that the institutional variable to a positive impact on economic performance. So, to have sustainable economic growth must improve the quality of political institutions.

Figure (2) shows that the stability policy has a key role in the sustainability of economic performance. Indeed, we note though, for our sample, there is a positive relationship between the two variables. And subsequently the quality of governance as measured by political stability had a positive impact on economic growth.

In fact, taking as a measure the quality of political institutions Bureaucratic Quality and the average annual growth in GDP per capita as a measure of economic performance for the year 2011, we note the positive correlation between the two variables. Therefore, for sustainable economic growth, it must be independent in administration from political pressure and the credibility and transparency of the government's reform commitments and policies.

Based on figure (4), we see that there is a positive relationship between average annual growth in GDP per capita and Regulatory Quality. Therefore, we must liberalize the economies of developing countries and adopt the policy of market economy and it aimed to encourage trade and promote the business climate.

According to figure (5), we can see well in 2011 and a sample of thirty developing countries, there is a positive correlation between the two variables. Indeed, for sustainable economic growth must respect the laws and rules of society is this aimed to mitigate the negative effects of crime and have a legal system and legal contracts more effective.

Figure (6) shows that there is a positive relationship between economic growth and control of corruption. Thus, these last adverse effects on indicators of economic 
performance. For this reason, and to combat corruption must be of good institutions that are characterized by incentive structures and laws that reduce uncertainty and support the efficacy (A. Bouzid, 2012). Similarly, we must democratize political institutions in developing countries to mitigate the negative effects of corruption and then promote sustainable economic growth.

\section{Econometric Analysis of the Interaction Political Institutions and Economic Growth in Developing Countries}

In this context, this work will be devoted to determine the effects of political institutions on the economic growth in developing countries.

\section{Specification of the Econometric Model}

We seek to test the extent to which institutional variables affected the economic growth of developing countries for the period between 1998 and 2011. We intend to study the example of thirty countries. In fact, following the work of Mankiw, Romer and Weil (1992), Knight et al., (1992, 1993), Ghura and Hadjimichael (1996), and Demetriades and Law (2006), the objective of our empirical study, is to add institutional variables to our model whose indigenous variables are indicators of economic performance such as average annual growth in GDP per capita. Therefore, we consider the following model:

$$
\begin{aligned}
& \Delta y_{i t}=\alpha_{i}+\beta_{1} R_{i t}+\beta_{2} S_{i t}+\beta_{3} Q_{i_{i t}}+ \\
& \beta_{4} Q R_{i t}+\beta_{5} \mathrm{Ed}_{i t}+\beta_{6} C_{O R R}+\varepsilon_{i t}
\end{aligned}
$$

With the individual specific effect, $\beta 1, \beta 2$, $\beta 3, \beta 4, \beta 5$ and $\beta 6$ are parameters to be estimated and $\varepsilon_{\text {it }}$ is the error term.

\section{Database and Presentation Variables}

In this study, we empirically investigate the interaction between institutional variables and economic growth, using a macroeconomic indicator and institutional indicators calculated over several years and taken from different databases.

\section{Macroeconomic Variable}

The indicator of macroeconomic performance used in this work is represented by $(\Delta y)$ the average annual growth in GDP per capita. The actual macroeconomic variable is taken from the database of the World Bank (WDI, CD-ROM, 2011).

\section{Institutional Variables}

Institutional variables are recorded in the database "International Country Risk Guide (ICRG)" owned by Political Risk Services. This database includes more than 75 data sets over 140 countries, covering the period from 1984 to the present. It relates the economy and foreign trade, risk assessment to economic, political and social indicators.

In this analysis, we will try to measure the effect of the legal and democratic economic development of developing countries. At this level, we used six indicators database (ICRG), which are the Democratic Responsibility (RD), Stability Policy (SP), Bureaucratic Quality (QB), the Regulatory Quality (RQ), the State Rights (ED) and the index of corruption (CORR). Notes indicator; indicators RD, ED, and QR CORR range from 0 to 6. Quality Bureaucratic is 0 to 4. Finally, the Political Stability of 0 to 12.

Thus, higher scores indicate better institutional qualities, in other expression, greater democratic accountability, a more effective judicial system, a better bureaucracy, less corruption, better quality and low bureaucratic government instability.

\section{Econometric Strategy}

Specification Tests or Tests of
Homogeneity

To estimate our baseline model by appropriate techniques, we will use the specification tests or homogeneity. These tests are based on statistics of Fisher. This is to determine how our model must be specified, if the Panel hypothesis can be accepted. We will see that our analysis is 
then based on the notion of homogeneity of parameters of our model. These specification tests aim to make a diagnosis and the possible need to integrate heterogeneous dimension(s) and to show how this heterogeneity must be specified. Thus, if the constants are fixed, then heterogeneity is detected only in the constant, and in this case we use the techniques or Least Squares Within Dummy Variables (LSDV) to estimate our model individual effects. By cons, if these constants are random, then we use the method of Generalized Least Squares (GLS) to estimate our model.

In fact, econometrically this amounts to testing the equality of coefficients of our theoretical model studied in the individual dimension. On the economic front, the specification tests back to determine if it is reasonable to assume that the impact of institutional variables on economic growth and identical for all developing countries, or on the contrary, there are specific to each countries.

Table 1: Specification Tests or Tomogeneity

\begin{tabular}{|c|c|c|}
\hline & Heterogeneity constants & $\begin{array}{c}\text { Homogeneity } \\
\text { Coefficients }\end{array}$ \\
\hline$\Delta y_{i t}$ & $\mathrm{~F}(29,384)=165.12$ & $\mathrm{~F}(6,384)=0.45$ \\
& $\mathrm{Prob}>\mathrm{F}=0.0000$ & Prob $>\mathrm{F}=0.8636$ \\
\hline
\end{tabular}

Source: Authors calculations

From this table, we can see that there are homogeneity coefficients, since the value is greater than $10 \%$. For cons, the constants are heterogeneous since the value is less than $10 \%$. We used the method of panel data, considering the specific effects of individual countries to capture their economic and institutional differences. Hausman tests must show how estimation method, we must remember.

\section{The Unit Root Tests on Panel Data}

Econometric techniques of unit root tests have become a common approach to the analysis of stationary time series. The extent of these techniques on panel data is recent. Existing work in these areas are those of Levin and Lin (1992, 1993), Im, Pesaran and Shin (2003), Harris and Tzavalis (1999), Maddala and Wu (1999), Choi. I (2001), Choi. I (2002), Hadri (2000) and Chang (2002). For our study, we use the test of Levin-Lin-Chu (LLC, 2002).

The table below corresponds to the unit root test of Levin-Lin-Chu (2002) for the variable GDP / capita and institutional variables.

Table 2: Statistics stationarity LLC (2002)

\begin{tabular}{|c|c|c|}
\hline Variable & With constant & With constant anad trend \\
\hline$\Delta y_{i t}$ & -0.5787 & $-13.8219^{*}$ \\
& $(0.2814)$ & $-6.0000)$ \\
\hline $\mathrm{RD}_{\mathrm{i}}$ & $-5.3451^{*}$ & $(0.0000)$ \\
\hline $\mathrm{SP}_{\mathrm{i}}$ & $(0.0000)$ & $-5.3278^{*}$ \\
& $-4.8053^{*}$ & $(0.0000)$ \\
\hline
\end{tabular}




\begin{tabular}{|c|c|c|}
\hline Variable & with constant & With constant and trend \\
\hline $\mathrm{QB}_{\mathrm{i}}$ & $-4.0213^{*}$ & $-2.0563^{*}$ \\
& $(0.0049)$ & $(0.0051)$ \\
\hline $\mathrm{QR}_{\mathrm{i}}$ & $-9.4806^{*}$ & $-9.1738^{*}$ \\
& $(0.0000)$ & $(0.0000)$ \\
\hline $\mathrm{ED}_{\mathrm{i}}$ & $-2.7019^{*}$ & $-2.9281^{*}$ \\
& $(0.0034)$ & $(0.0017)$ \\
\hline $\mathrm{CORR}_{\mathrm{i}}$ & $-3.9884^{*}$ & $-2.9571^{*}$ \\
& $(0.0000)$ & $(0.0016)$ \\
\hline
\end{tabular}

Source: Authors calculations

From this table (2), we note that all the following variables are stationary in levels except for average annual growth in GDP per capita (case without trend) since the calculated values of test statistics LLC (2002) are less than the critical value of the standard normal distribution the risk threshold of $5 \%(-1.645)$.

\section{Direct Effects of Political Institutions on Economic Growth}

We will endeavor to show the impact of political institutions on economic growth: the case of developing countries. The Hausman test (1978) to show what method, we must remember. The estimation result is presented in the table below.

Table 3: Dependent variable: $\Delta y_{i t}$

\begin{tabular}{|c|c|c|}
\hline Variable & Within & GLS \\
\hline Constante & $\begin{array}{c}3.20 \\
(20.30)\end{array}$ & $\begin{array}{c}3.04 \\
(16.79)\end{array}$ \\
\hline $\mathrm{RD}_{\mathrm{i}}$ & $\begin{array}{c}0.17 \\
(1.66)^{* * *}\end{array}$ & $\begin{array}{c}0.18 \\
(1.79)^{* * *}\end{array}$ \\
\hline $\mathrm{SP}_{\mathrm{i}}$ & $\begin{array}{c}0.22 \\
(1.57)^{* * *}\end{array}$ & $\begin{array}{c}0.22 \\
(1.60)^{* * *}\end{array}$ \\
\hline $\mathrm{QB}_{\mathrm{i}}$ & $\begin{array}{c}0.04 \\
(0.22) \\
\end{array}$ & $\begin{array}{c}0.23 \\
(1.16) \\
\end{array}$ \\
\hline $\mathrm{PR}_{\mathrm{i}}$ & $\begin{array}{c}0.21 \\
(2.55)^{* *}\end{array}$ & $\begin{array}{c}0.21 \\
(2.52)^{* *}\end{array}$ \\
\hline$E D_{i}$ & $\begin{array}{c}-0.36 \\
(-2.32)^{* *}\end{array}$ & $\begin{array}{c}-0.26 \\
(-1.73)^{* * *}\end{array}$ \\
\hline $\mathrm{CORR}_{\mathrm{i}}$ & $\begin{array}{c}-0.18 \\
(-2.16)^{* *}\end{array}$ & $\begin{array}{c}-0.17 \\
(-2.05)^{* *}\end{array}$ \\
\hline $\mathrm{N}^{\mathrm{a}}$ & 420 & 420 \\
\hline $\mathrm{R}^{2}$ & 0.068 & 0.1 \\
\hline $\begin{array}{l}\text { t-Hausman } \\
\text { P-Values }\end{array}$ & & $\begin{array}{l}15.32 \\
(0.018)\end{array}$ \\
\hline \multicolumn{3}{|c|}{$\begin{array}{l}\text { Note: The values between parentheses represent statistics student, }\left({ }^{* *}\right) \text { significant at } 1 \% \\
\text { level, }\left({ }^{* *}\right) \text { significant at } 5 \% \text { level }(*) \text { significant at } 10 \% \text { level. a Number of observation }\end{array}$} \\
\hline
\end{tabular}


According to the table, we can conclude that our model is specified by a panel with fixed individual effects since the Hausman statistic is greater than the critical value of chi-square with six degrees of freedom $\left(\chi^{2}(6)=12.59\right.$ for $\alpha=5 \%$ ). In this case, the estimate with (unbiased estimator) is most appropriate.

Based on the results of Table (3), it shows that there is a good correlation between the quality of political institutions and economic growth, except in the case of the rule of law indicator (ED). On the other hand, corruption has a negative correlation with economic performance.

Indeed, we can conclude that the indicators that are meaningful, those that have higher coefficients have the most important role in enhancing economic growth are the Regulatory Quality (PR, 0.21), Responsibility democratic (RD, 0.17) and Political Stability (SP, 0.22). In fact, Bureaucratic Quality indicator positively affects economic growth but no statistical significance. However, indicators States law (ED; -0.36) and corruption index $(-0.18)$ negatively affect the economic growth of developing countries.

But, without giving too much attention to the sign of these coefficients, we can conclude that institutional variables have a positive correlation with economic performance. This result is similar to theoretical explanations treated by North (1990), Knack and Keefer (1995), Chang and Calderon (2000a), Acemoglu et al., (2001) and Assane and Grammy (2003).

Accordingly, we can confirm that the quality of political institutions does not necessarily lead to beneficial outcomes such as high economic growth, but it can be so bad that the persistence of results becomes less likely. These results are based on the implementation of good policies.

Nevertheless, corruption has adverse effects on economic growth. So we can conclude that the causes for the high level of corruption causing subsequent poor economic performance of developing countries, is the presence of democratic political institutions less or sometimes non-democratic developing countries.

\section{Conclusion and Policy Recommendations}

The quality of political institutions is a rule of the game. It is important in determining the form of economic behavior and in explaining the economic performance of countries. Indeed, this work has focused on empirically studying the interaction between the quality of political institutions and economic performance for a group of 30 developing countries over the period 1998-2011.

Thus, we conclude that the institutional failures that characterize developing countries inevitably lead to destabilize their long-term economic growth. However, a higher degree of democratization would be a better improvement in economic growth.

Similarly, corruption was one of the main institutional failures representatives in developing countries. However, there is no doubt that corruption has a detrimental impact on economic performance. Therefore, it is clear that corruption is more severe in countries with low income levels that are less integrated into the global economy and are generally the most populous.

The political determinants of this problem can be explained by a lack of democracy increases corruption this is in accordance with the theory of Olson (1982) shows that the most stable democracies in the long run retreat activities more clearly rent-seeking. However, this corruption was a higher level in developing countries suffering from a weak legal system and poor quality of bureaucrats who earn low wages.

\section{References}

Acemoglu, D., Johnson S. and Robinson, J. A. (2001), "The Colonial Origins of Comparative Development: An Empirical Investigation." American Economic Review 91, 369-1401. 
Acemoglu, D., Johnson, S. and Robinson, J. A. (2002), "Reversal of Fortune: Geography and Institutions in the Making of the Modern World Income Distribution," NBER Working Paper $n^{\circ} 8460$.

Chang, Y. (2002), "Nonlinear IV Unit Root Tests in Panels with Cross-Sectional Dependency, "Journal of Econometrics, 110, $261-292$.

Charreaux, G. (1997), "Corporate Governance, theories and facts," Edition Economica.

Choi, I. (2001), "Unit Root Tests for Panel Data," Journal of International Money and Finance, 20 (2), 249-272.

Choi, I. (2002), "Combination Unit Root Tests for Cross-Sectionnally Correlated Panels," Mimeo, Hong Kong University of Science and Technology.

Chong, A. and Calderon, C. (2000a), "Institutional Quality and Income Distribution. Economic Development and Cultural Change," University of Chicago Press, 48 (4), 76-86.

Cornelious, P. and al. (2002), "The Growth Competitiveness Index: Recent Economic Developments and the Prospects for a Sustained Recovery, v: Global Competitiveness," Report 2002-2003, World Economic Forum, Geneva.

Demetriades, P. and Law, S. (2006), "Finance, institutions and economic development," International Journal of Finance \& Economics, 11(3), 245-260.

Dollar, D. and Kraay, A. (2003), "Institutions, trade, and growth," Journal of Monetary Economics, Elsevier 50 (1), 133162.

Easterly, W. and Ross, L. (2003), "Tropics, germs, and crops: how endowments influence economic development," Journal of Monetary Economics, Elsevier 50 (1), 339.

Frischtak, L.L. (1994), "Governance Capacity and Economic Reform in
Developing Countries," World Bank Technical Paper NO 254.

Ghura, D. and Hadjimichael, M. (1996), "Growth in Sub-Saharan Africa," International Fund Monetary Staff Papers, 43 (3), 605-631.

Hadri, K. (2000), "Testing for Unit Roots in Heterogeneous Panel Data," Econometrics Journal, 3 (2), 148-161.

Hall, R. E. and Jones Charles, I. (1999), "Why Do Some Countries Produce So Much More Output Per Worker Than Others?" The Quarterly Journal of Economics, MIT Press, 114 (1), 83-116.

Harris, R. D. F. and Tzavalis, E. (1999), "Inference for Unit Roots in Dynamic Panels where the Time Dimension is Fixed," Journals of Econometrics, 91(2), 201-226.

Hausman, J. (1978), "Specifications tests in econometrics," Econometrica, 46 (6), 12511271.

Hu, F. and Sachs J. D. (1997), "Executive Summary, in: The Global Competitiveness," Report 1997, World Economic Forum, Geneva.

Im, K. S., Pesaran, M. H. and Shin, Y. (2003), "Testing for Unit Roots in Heterogeneous Panels," Journal of Econometrics, 115 (1), 53-74.

Kaufmann D., Kraay A. and Zoido-Lobaton P. (1999), "Institutions, and Growth," World Bank Working Paper, $N^{\circ} 2448$.

Kaufmann D., Kraay A., Mastruzzi M. (2003), "Governance Matters III. Governance Indicators for 1996- 2002," World Bank Policy Research Working Paper, $n^{\circ}$ 2772, Washington D.C.

Kaufmann, D. and Kraay, A. (2002), "Growth without Governance".World Bank Working Paper, Washington D.C.

Knack, S. ( 2002), "Governance and growth, measurement and evidence". Forum Series on the role of Institutions in Promoting 
Economic Growth; IRIS Center, Washington D.C.

Knack, S. and Keefer, P. (1995), "Institutions and Economic Performance: Cross country Tests Using Alternative Institutional Measures, " Economics and Politics, 3(7): 207-227.

Knight, N. and al (1993), "What we know about the socio-economic impacts of Canadian megaprojects: An annotated bibliography of post-project studies. Centre for human settlements, University of British Columbia, Vancouver.

Levin, A. and Lin, C. F. (1992), "Unit Root Test in Panel Data: Asymptotic and Finite Sample Properties," University of California at San Diego, Discussion Paper, 92-93.

Levin, A. and Lin, C. F. (1993), "Unit Root Test in Panel Data: New Results," University of California at San Diego. Discussion Paper, 93-56.

Levin, A., Lin, C. F. and Chu, C. S. J. (2002), "Unit Root Test in Panel Data: Asymptotic and Finite Sample Properties," Journal of Econometrics, 108 (1), 1- 24.
Maddala, G. S. and Wu, S. (1999), "A comparative Study of Unit Root Tests with Panel Data and a New Simple Test," Oxford Bulletin of Economics and Statistics, special issue, 631- 652.

Mankiw, N. G., Romer, D. and Weil, D (1992) A Contribution to the Empirics of Economic Growth. The Quarterly Journal of Economics, MIT Press, 107(2), 407-37.

North, D. C. (1990), "Institutions, Institutional Change and Economic Performance, " New York: Cambridge University Press.

Rodrik, D., Subramanian, A. and Trebbi, F. (2004), "Institutions Rule: The Primacy of Institutions over Geography and Integration in Economic Development," Journal of Economic Growth, 9, 131-165.

Schneider, F. (2005), "Shadow Economies around the world: What do we really know?" European Journal of Political Economy. 21(3), 598-642. 